\title{
Possible future of the Visual Soil Assessment
}

\author{
Zoltán KENDE - Márta BIRKÁS \\ Szent István University, Institute of Crop Production, H-2100 Gödöllö, Páter K. u. 1; \\ E-mail: kende.zoltan@mkk.szie.hu
}

Keywords: index, soil assessment, development, mobile application

\section{Introduction}

In 2000, Sheperd published a field guide for the Visual Soil Assessment (VSA) method by the FAO. The VSA provides a quick and simple method to assess soil condition and plant performance. It can also be used to assess the suitability and limitations of a soil for crop production. Based on the user manual the method provides a visual scoring system, where the user must examine10 different soil and crop indicators. Each indicator is given a visual score (VS) of 0 (poor), 1 (moderate), or 2 (good), based on the soil quality and plant performance observed when comparing the soil and plant with three sample photographs in the field guide manual. Since some soil and plant indicators are relatively more important in the assessment of soil quality and plant performance than others, VSA provides a weighting factor of 1,2 and 3. The total of the VS rankings gives the overall Soil Quality Index and Plant Performance Index for the site. Compare these with the rating scale at the bottom of the scorecard to determine whether your soil and plants are in good, moderate or poor condition (Sheperd et al., 2008).

Although, the VSA method provides a Soil Quality Index (SQI) and a Plant Performance (PPI) Index, nowadays these indexes are not entirely suitable to help the farmers and the professional extension service's needs. The professionals need a decision support method, because of the climate change and the global warming. There are several dynamic and rapid condition changes over the growing season in the crop production (Jolánkai et al., 2016), which needs quick reactions and interventions from the farmers side to prevent yield loss (Kassai et al., 2016). The heavy rainfalls and storms, the uneven precipitation distribution, the extreme long droughts, floods, and permanent temperature changes are called together extreme climate events which are decreasing the ability of crop production especially when the soils are inappropriate condition to enable crop production and moreover, to prevent the climate induced damages of soils. The unfavourable soil conditions are induced by natural processes however, most of them are endangered by human activities including improper soil tillage. Thus, all unsatisfactory man-made soil conditions will increase the effects of the climate events on soils and yield loss (Birkás, 2011; Bottlik et al., 2014). The VSA method is a slower process which needs accurate preparation, because at least 9 different equipment needed on the field for the work and it is use paper-based data collection.

One year ago, we started to work on a new improved index and system which unites and complements several currently used indexes like SQI and PPI etc. The new index would be the Climate Sensitivity Index (CSI) that may help the farmers and other professionals to identify their problem with the examined fields, soils and crop production.

\section{Materials and methods}

A long-term tillage experiment was initiated at the Training Farm of the GAK Ltd., nearby the town, Hatvan (47 41'31.7" N 19 36' 36.1" E, 110 m a.s.l), in year 2002 with a soil 
of a clay-loam texture, Endocalcic Chernozems, Loamic (WRB 2015). The one-factorial experiment was arranged in a randomised block design (SVÁB 1981) with four replicates. Plot size was $13 \mathrm{~m} \mathrm{x} 185 \mathrm{~m}$. Five ploughless tillage treatments (loosening, 0.4-0.45 m), tine tillage (a deeper, 0.22-0.25 m, and a shallower, 0.18-0.22 m), disk tillage (0.12-0.16 $\mathrm{m}, \mathrm{D})$ and direct drilling (DD) were compared with the mouldboard ploughing (0.30$0.34 \mathrm{~m}$ ). Total area of the trial including edges covers 6.2 hectares. Samples to check soil condition and moisture content were taken in 30-day intervals from March till November in each treatment in five repetitions (Bottlik et al., 2014, Kende et al., 2017). Based on the soil condition data we started to determine the basic elements of the index, which now uses 11 different parameters. Because of the CSI would be a full decision helper system, we also worked on a simple sampling method which decrease the amount of hardware which needed on the field for the professionals. We developed a digital data recording method, which basically a cross platform mobile and web application which based on mainly HTML5 and JavaScript code with geolocation services and it can save the recorded data into cloud services.

\section{Preliminary results and conclusions}

Based on the preliminary results this new CSI system will be usable because it could help for farmers, professionals and for scientists to make more precise decisions, scenarios and models to prevent the soil damages and yield loss by giving them a high resolution adaptable data and information for better decisions, however, the development is not finished yet, we need to validate our Index and test the system.

The developed web application will be available widely for testing in the second half of 2019 in the Hungarian Tillage Research Organization's website, as well the mobile application in the respective stores for free.

\section{Acknowledgement}

Our research and this publication were supported by the Hungarian Tillage Research Organization. Authors thank for the outstanding grant to the Szent István University and to the GAK Nonprofit Közhasznú Kft.

\section{References}

Birkás M. (2011): Tillage, impacts on soil and environment. In: Glinski, J., Horabik, J., Lipiec, J.:eds.. Encyclopedia of Agrophysics. Springer Dordrecht, 903-906.

Bottlik, L., Csorba, Sz., Gyuricza, Cs., Kende, Z., Birkás, M. (2014): Climate challenges and solutions in soil tillage. Applied Ecology and Environmental Research 12:(1),13-23. DOI: https://doi.org/10.15666\%2Faeer\%2F1201_013023

Jolánkai, M., Tarnawa, Á., Horváth, Cs., Nyárai, H.F,.Kassai, K. (2016): Impact of climatic factors on quantity and quality of grain crops. Időjárás. 120. 1. 73.84 pp

Kassai, M.K., Tarnawa, Á., Nyárai, H.F., Horváth, Cs., Jolánkai, M. (2016): Water availability and protein formations interrelations. Acta Hydrologica Slovaca. 17. 2. 260-264 pp.

Kende, Z., Sallai, A., Kassai, K., Mikó, P., Percze, A., Birkás, M. (2017): The Effects of Tillage-Induced Soil Disturbance on Weed Infestation of Winter Wheat POLISH JOURNAL OF ENVIRONMENTAL STUDIES 26 : 3 pp. 1131-1138. , 8 p. DOI: https://doi.org/10.15244\%2Fpjoes\%2F67552

Shepherd, T.G. (2000): Visual Soil Assessment. Volume 1. Field guide for cropping and pastoral grazing on flat to rolling country. horizons.mw \& Landcare Research, Palmerston North. 84p http://orgprints.org/30582/1/ VSA_Volume1_smaller.pdf

Shepherd, G., Stagnari, F., Pisante M., Benites, J. (2008): Visual Soil Assessment Field Guide for Wheat. FAO, Rome. 62p http://www.fao.org/tempref/docrep/fao/010/i0007e/i0007e05.pdf

doi: 10.34116/NTI.2019.AA.37 